\title{
Improving of Offinso College of Education (OFCE) Demonstration Basic Four (4) Pupils' Ability to Understand the Concept Rusting Through Activity Method
}

\author{
Victus Nangkuu ${ }^{*}$ Dip. Sampson Adjei Kankam ${ }^{1}$ Med. Kwame B. Bour ${ }^{2}$ MPhil Francis Boateng ${ }^{3}$ Med \\ *12. Offinso College of Education, Offinso-Ashanti, Ghana W/A \\ 3. Agona SDA College of Education, Agona-Ashanti, Ghana W/A
}

\begin{abstract}
The objective of this action research was to enhance the understanding of pupils in Offinso College of Education basic practice school. The documented positive impact of helping pupils was purposely to enhance the understanding of pupil's knowledge in the concept of rusting. The researcher used observation, interview and questionnaire as the research instrument to gather information about pupils' previous and current performances before and after the intervention studies was implemented. The researcher used activity based methods to assist the pupils of Offinso College of Education Demonstration basic four to overcome their challenges relating to the concept rusting. Based on the findings, the researcher recommended that, activity oriented methods of teaching that engages learners should be employed to cause the interest of pupils to overcome their challenges in science, especially on the concept rusting.
\end{abstract}

\section{Keywords: Activity based Method, Rust, Context Based Teaching Approach,}

\section{Background of the Study}

(Harper 2014) "Science from the Latin word Scientia, meaning "knowledge". Heilbron (2003), science is a systematic enterprise that builds and, organizes knowledge in the form of testable explanations and predictions about the universe. Science is based on research, which is commonly conducted bin academic and research institutions as well as in government agencies and companies. The practical impact of scientific research has led to the emergence of science policies that seek to influence the scientific enterprise by prioritizing the development of commercial products, armaments, health care and environmental protection (Wikipedia 2019). The prompt of the researchers to write on integrated science as a teacher trainee at Offinso college of education practice school is that teachers in class four have been teaching "rusting" without using appropriate concrete materials and methodology (Activity method of teaching to prove the learning ability of pupils.

All the same, science is viewed as a process of theory change. This view places emphasis on the parallel between historical and philosophical aspects of science (Kuhn, 1962) and the domains of cognitive development (Carey, 1985); Koslowskii, 1996) in which domain-specific knowledge involves via the gradual elaboration of existing theories through the accretion of new facts and knowledge (normal science, according to Kuhn), punctuated, occasionally, by the replacement of one theoretical framework by another. The science -as-theory perspective places its emphasis less on the mastery of domain-general logic, heuristics, or strategies and more on. This discussion of the different views of science is based on Lehrer and Schauble (2006).

From the above points clearly explained by expects science can be said as a unique field of study where knowledge is obtained through a specified processes to make good predictions about the universe. The researcher on this note therefore wants to improve the understandings of the concept rusting. The concept of rusting is a broad spectrum encompassing materials that rust, causes of rusting, effects of rusting on iron, cleaning of rust from iron and prevention of rusting. Sund (1980) "Rust is another name for iron acid which 
occurs when iron or an alloy that contains iron, like steel, is exposed to oxygen and moisture for a long period of time. Over time, the oxygen combines with the metal at an atomic level, forming a new compound called an acid and weakening the bonds of the metal itself. (Gallagher, 2000; Gardner \& Boix Mannmsila, 1994; National Research Council, 1998, Prawat, 1994' Wildey \& Wallace, 1995) for some time, the service education community has shown considerable support for teaching for understanding. (Kratf, Christopher \& Atwood 2009), during the same period, it has been well documented that diverse scientific understanding of many fundamental science concepts across the biological, earth and physical science.

Rusting is one of the important concepts the pupils must know even from the early days of schooling. That is because rusted metals all over the place; at homes, schools and around the community. They must understand the concept of if how it is caused and some other simply possible ways of preventing them from occurring. Despising this knowledge about a common concept, pupils do not get the understanding of the concept when taught in abstract using inappropriate methodology. As a result of pupils' inability to answer written questions on the said topic and other similar ones, pupils started showing encouraging interest when it was time for the teaching and learning of science.

\section{Statement of the Problem}

Gareth (2002), reports by students of their poor experience of science education of which (rusting as a concept is not left out) led to the implementation of ten-year "Science and innovation investment framework 2004-2014. Treasury (2004). Yet while, the strategy makes some useful references to the teacher supply and curriculum issues. During the researchers teaching practice attachment programme at OFCE Demonstration Primary it came to notice through a science lesson that the pupils in basic four (4) could not understand the concept rusting, and that a good number of pupils of about seventy (70\%) percent could not understand the concept. This is a good reflection of Gareth (2002) reports that students have poor performance to science and that some clear factors can be a source to these challenges. This cannot be said without making reference to the supply of teachers teaching aids and the curriculum. The researcher upon realizing the challenge faced by the pupils offered a helping hand to assist pupils to improve pupils understanding to easily through activity method.

\section{Purpose of the Study}

The project is purposely designed to :

- Consider the factors responsible for the students in ability to grasp the concept rusting

- Develop proper methodology to improve the concept rusting

- Improve upon the activity method of teaching the concept rusting.

Carey (1985), posited that the idea that understanding is domain specific and central to thinking about conceptual undertaking and change. As such, the project of study is aimed at equipping teachers the need to use external factors and right methodology (Activity Based Learning) to enhance learner (pupils) understanding of the concept rust and thereby arousing the interest in science education at large.

\section{Research Questions}

In other for the researcher to effectively recommend a remedy, the researcher constantly asks certain vital questions. Some of the questions include the few below.

1. What is the "concept rusting" as per pupils thinking and perceptions to it?

2. What are some of the opposing factors against the concept?

3. How can the concept be rusting $b$ taught effectively and efficiently through activity based learning and referred to as activity method of learning?

\section{Significance of the Study}

The significance of the study looks at abilities to enhance pupils understanding in the concept rusting which is one of the scientific topics treated from the lower level of the academics to the higher levels. The 
main aspirations of the study will look at the teaching and learning of the concept rusting using activity based method of teaching and learning. The study will be useful to teachers and to curriculum planners to effect the necessary changes in curriculum planning to meet the required needs of pupils in terms of teaching strategies that will help pupils to develop good understanding.

\section{Concept of Rusting}

Robert (1980), rust is another name for iron oxide which occurs when iron or an alloy that contains iron, like steel, is exposed to oxygen and moisture for a long period of time. Over time, the oxygen combines with the metal at an atomic level, forming a new compound called an oxide and weakening the bonds of the metal itself. David, D.M. (2007), rust is an iron oxide a usually red oxide formed by the redox reaction of iron and oxygen in the presence of wonder or moisture. Several forms of rust are distinguishable both visually and by spectroscopy, and form under different circumstances. Rust consists of hydrated iron (III) oxides $\mathrm{Fe} 2 \mathrm{O} 3 . \mathrm{nH} 2 \mathrm{O}$ and iron (III) oxide hydroxide $(\mathrm{FeO}(\mathrm{OH}), \mathrm{Fe}(\mathrm{OH}) 3)$. Stambolou (1985), who quotes many publications the most commonly found corrosion products in soil are magnetite and goethite. The reason for this is explained by Turgoose (1982) who also proposes a model for corrosion of iron in soil. This model includes the anodic reaction of iron oxidation to ferrous irons and the cathode reduction of oxygen to hydroxide ions. Rust model described above is in accordance with established corrosion theory and seems to give a reasonable explanation in the reaction of a metal (iron) in relation to the environment with wear and tear away of its surface. As a researcher, rust can be of the concept the outcome of metal (iron) when it reacts with the environment.

\section{What is Rust?}

(Encyclopedia (2019), reports rust is a type of corrosion. It happens to iron and its alloys when it is exposed to air or water for a long time. Rust slowly decomposes iron into other chemical, because of a reaction with the oxygen molecules. Both air and water are needed for rust. (Oxford Dictionary 2009) reports rust a reddish - or willowish -brown flaky coating of iron oxide that is formed on iron or steel by oxidation, especially in the presence of moisture. (Concise Oxford Dictionary 1996), defines rust as brownish coating formed on iron and steel by oxidation. OE rust=OS., (O) HG.rost.(M) Du.roest, rel. to RED. Hence vb. XIII. rusty (-YL) OE, rusting. (ASM 2000) rust can be defined as corrosion, which generally means to eat into or wear away gradually, as if by gnawing. Corrosion can be defined as a chemical or electrochemical reaction between a material, usually a metal, and its environment that produces a deterioration of the material and its properties.

To the researcher, rusting is a chemical reaction which causes the wearing of a metal (iron) which occurs mostly in the presence of moisture and oxygen. The chemical process causes the metal to change in colour.

\section{Causes of Rust}

Sund (1980), corrosion are more specifically, rust is caused by one of three general factors
i. $\quad$ Process related
ii. Packaging related
iii. Environmental related

\section{Process Related}

Whether it is the cleaning process, the fabrication process such as cold working, heat treating or machining or the handling process, the aspect of producing a metal part is a primary contributor of corrosion.

\section{Packaging Related}

The type of packaging used to package metal materials such as corrugated and non-treated paper can hold moisture and cause corrosion. Sometimes in a companies' desire to fix a corrosion problem, they add more packaging, when in fact the additional packaging can contribute even more to the rust problem. 


\section{Environmental Related}

The weather [temperature and humidity] can certainly be the most obvious environmental factor; other things such as contaminants in the air pose equal areas of concern.

Schonbein (1836) showed that iron could be made passive. It was left to U.R. Evans to provide a modern understanding of the causes and control of corrosion (rust) bases on his classical electrochemical theory in 1923. AHMAD (2006), reported "all environments are corrosive to some degree. Following is the list of typical corrosive environments:

1. Air and humidity

2. Fresh, distilled, salt and marine water

3. Natural, urban, marine and industrial atmospheres

4. Steam and gases, like chlorine

5. Ammonia

6. Hydrogen sulfide

7. Sulfur dioxide and oxides of nitrogen

8. Fuel gases

9. Acids

10. Alkdies

11. Soils. These are potent forces which destroy economy, deplete the resources and causes CO3Hy and untimely failures of metal.

Combinations of some alloys and environments that have been shown to promote corrosion cracking

\begin{tabular}{|l|l|}
\hline Material & Environments \\
\hline All alloys & Chlorides, moist air \\
\hline Mg alloys & $\begin{array}{l}\text { Chloride-Chromate mixtures, moist air, } \\
\text { Nitric acid, fluorides sodium hydroxide }\end{array}$ \\
\hline $\mathrm{Cu}$ alloys & $\begin{array}{l}\text { Ammonia, most air, moist Sulphur } \\
\text { dioxide }\end{array}$ \\
\hline C steels & $\begin{array}{l}\text { Nitrates, hydroxides, carbonates, } \\
\text { Anhydrous ammonia }\end{array}$ \\
\hline Austenitic steels & Chlorides, Sulphur acid \\
\hline High strength steels & $\begin{array}{l}\text { Moist air, water, chlorides, Sulphur } \\
\text { sulphides }\end{array}$ \\
\hline Ni alloys & Hydroxides \\
\hline Ti alloys & Halides, methanol \\
\hline
\end{tabular}

To the researcher, if can be clearly seen that three are many things that bring about corrosion and in that case rust. The process of producing the metal and the packaging of it can lead to rust by the persisting cause of rusting is the environmental related issues. And this includes:

Carlsten (2002), all water contains ions, some of which care aggressive and can cause corrosion of most metals. High temperature and humidity in the presence of moisture and oxygen. Higher $\mathrm{Ph}$ GREATER (z) than protecting ferrous metals but negatively affecting the staining control of non-ferrous includes aluminums, brass and bronze. Others includes -sea water, acids, alkalies, ammonia and soils.

\section{Type of Rust}

Rust can be grouped into different type considering its colour: These are as follows:

- Red rust 
Read rust- Hydrated oxide Fe2O3.H2O (high oxygen water exposure. Rust from ion(III) oxides forms due to high oxygen and exposure.

Yellow rust-Rust from iron (III) oxides, that is a very soluble iron oxide results in yellow rust.

Brown rust - Oxide Fe2O3 (high oxygen/low moisture) is mostly atmospheric and sometimes appears as non-uniform sports rather than over the whole surface.

\section{Approaches to the Teaching of Science}

[CEI, 2009; EC , 2007; EIRMA, 2009; Jenkins \& Nelson, 2005, van Adsvoort, 2004) suggest that the approaches educators use to teach science could be a major determinant of learner performance. IET, (2008) reported that lack of resources and competent science educators, poor infrastructure, the prevalence of large closes, and the types of instructional approaches, could influence the teaching and learning of science. CDE, (2010); Mji Makgatho (2006) have shown an association between teaching methods and learner instructional approaches to science subjects, namely; traditional teaching approaches, contextualized teaching and learning cydes, on learners performance. Many reports and studies EC, (2007); IET, (2008); Rennies et al (2001) imply that at primary school level, science teaching mostly at primary level, science teaching mostly involves pupil-centred and activity-based teaching, entailing frequent practical activities and providing more freedom for pupils investigations. In contrast, science teaching at high-school level usually involves educator-centered instruction; dominated by "chalk and talk" teaching, lecturing, note copying by learners, factual knowledge, abstract concepts and "cookbook' practical lessons and demonstrations. EC, (2007), Goodrum et al (2000), Onwu \& Stoffels (2005) Osborne \& Collins (2001).

\section{Activity Method and Development of Science in Solving and Decision-Making Ability}

Rennies et al., (2001), EIRMA (2009), IET; (2008), Lyons (2006), science is regarded by many people as a discipline based on practical and analytical activity. Instructional approaches in science are therefore expected to be premised on-hands and minds-on tasks. Such approaches are envisaged as enhancing the development of critical and analytical thinking skills, including science inquiry problem solving and decision-making ability. However, whole most of the science education schools consent to the sue of pedagogical practices based on inquiry-based methods, the reality of classroom practices is that science teaching is rarely inquiry based Allen (2008), EC (2007). Similarly, other higher order thinking skills such as decision-making and critical thinking are seldom developed. To the researcher, science is mostly taught in the normal watt without any practical's on the lessons taught. However, this should have been a hands-on and minds -on task. Runniest et al. But the wrong use of the right pedagogical approach result into learners losing interest in learning science.

\section{Context-Based Teaching Approach}

Oxford dictionaries Pearsall, (1999), defines contexts as: "the circumstances that form a setting for an event, statement, or idea, and the terms in which if can be fully understand. Bennett and Holman (2002) highlight examples of contexts with reference to chemistry teaching, which include economic, social, personal, technological and industrial applications of chemistry (science). In a similar vein, De Jong (2008) has attempted to clarify the meaning of contexts for science teaching and learning by identifying four domains as the origin of context. These are personal, social and society, professional practice and scientific and technological domains. Queensland studies Authority (2004:11) defines "context-based teaching as "a group of learning experiences that encourage learners to transfer their understanding of key concepts to situations that mirror real life. Similarly, Taylor \& Mulhall $(1997,2001)$ assert that contextualization of learning takes place when the learning materials and instructional methods are explicitly linked to the experiences and of the learners, Bennett, Lubben and Hagarthe (2006: 348) define context-based approaches to science teaching as "approaches adopted in science teaching where contexts and applications of science are used as the starting point for the development of scientific ideas". 
Based on Bennet, et al (2006)'s definition and the need to address learners' views, context-based teaching is defined in this study as approaches adopted in science teaching and learning where contexts determined by learners themselves and applications of science in familiar situations and experiences are used as starting points for developing scientific concepts and ideas, and for improving motivation".

\section{Research Design}

Dampson, \& Mensah, (2012), describe action research as inquiry process which focuses of how efforts can be made to improve the quality of organization of (school) and its performance. Action research is define by Johnson (2012) the bridge between research and practice. For instance, the theoretical components underpinning action practice are used to help practitioners understand and observe what is happening in the classroom setting. At the same time with the interest of best practice in mind, the collected data "are used to understand or inform theories and research related to best practice" (Johnson, p.20).

Action research is more of relevance to researcher hence Mills (2011) asserts that is an attractive option for teacher researchers, school administrative staff and other stakeholders in teaching and learning environment to consider. He further explained that, it provides practitioners with new knowledge and understand about how to improve educational practices or resolve significant problems in classroom and school. He also stated that "within education, the main goal of action research is to determine the ways to enhance the lives of children (Mills, 2011). The researcher has come to knowledge that, the goal of action research is to create a simple, practical, repeatable process of interactive learning, evaluation and improvement that leads to increasingly better results for schools, teachers and school programme. Action research can then be defined as a wide variety of evaluative, investigative and analytical research method designed to diagnose problems or weakness whet her organizational, academic or instructional and educators develop practical solution to address them quickly and efficiently.

Mills (2011) page 40, continue to state that because of the professional, reflective stance require by practitioners engaged in the action research sequence, teachers and further encouraged to "examine the dynamics of their classroom, ponder the actions and interactions of students, validate and challenge existing practices and take risks in the process. These specific action are similar to these regularly exercised by teachers on a daily basis. Using systematic and strategic action research plan provides those daily actions with increased structure, focus and methodology vigor. Action research has a broad spectrum of positive impact on pupils and teachers. Some of these include; if introduces teachers to new ideas in their professional development, it makes both pupils and teachers aware of learning strategies and it makes teachers acquire a special set of skills and competencies and also some of which have already been mentioned above. In spite of the advantages of action research, there are some weakness which include; lack of clarity of focus for the project, managing constraints of time and holding a pressured foreknowledge of the solution. The action research was seen as appropriate for this study because of the immediate solution and the time frame of the problem. And this will enhance the easy understanding of the concept rusting in Offinso College of Education Demonstration School.

\section{Population}

Vocabular7y (2015) defines population as the number of people in geographic area. The research was conducted in Offinso municipality in Ashanti Region of Ghana, in Offinso College of Education Demonstration School popularly known as OFCE basic school. The population for the research comprised of teachers, pupils and the head teacher of the school. The researcher decided to use primary four pupils because understanding the "concept rusting was one of its challenges in primary four science lessons. All elements that meet certain criteria for inclusion of this study population is included.

\section{Sample and Sampling Procedure}

Simple random sample (lottery method) was used the researcher, that is "Yes" and "No" were written on a slip of paper folded very well and mixed up in a box. Talking about the sample, it comprised of two primary four teachers and fifty pupils together with the head teacher of the school. The researcher chose the primary four teachers because they are expected to teach "rusting" in their various classes (Pilot and Hunler, 2004: 294). The sample size constituted of fifty (50) pupils out of one hundred and fifty (150) as the number of pupils in primary four (4). Gay (1981) suggested that, the minimum of the sample should be $10 \%$ with which generalization can be made. Owing to this suggestion by Gay, the researcher believed that with a 
better percentage of $33 \%$, valid generalization can be drawn. The size of the sample was not controlled by saturation of information which means, the (Streubert Speziale and Carpenter, 2003: 25) point at which repetition or confirmation of previous collected data occurs, thus these was a specific number of participants.

\section{Research Instrument}

Jackson (1968) commented that, it is always better to describe a classroom using different approaches. Relevant data in aid of the analysis was collected by the use of different instruments an instruments included observation, interview and test and they are discussed below; Firstly, the instrument used was the interview. And it can be defined briefly as a face-to-face interaction between the interviewer and the interviewee. The rationale behind the use of interview was that, some non-verbal behaviours can be examined form the respondent. It covered teachers' time spent on teaching the concept of rusting, availability and accessibility of magnet and magnetic substances to pupils and activities conducted during teaching and learning of the concept. Again, the second been observation was chosen for the reason that it is less time consuming and relatively inexpensive and also disproves presence. The observation guide covered teaching methods and accessibility of rust and rusted substances to pupils. The researcher further observed pupils when the lesson was taught. This helped the researcher to identify the level of misunderstanding of the concept of rusting.

Moreover, the third research instrument. Google web (2015) described a test as a procedure intended to establish quantity, performance or reliability of something in widespread especially was test. The instrument made the researcher to achieve the purpose of the study. It was used to find out how the pupils are coping and the understanding of pupils in the concept. Ary, Jacobs \& Rezaview (2002) explained that questionnaire can be answered more easily and quickly by respondents. They explained that questionnaire makes it easier for subjects to respond to questions on sensitive or private topic and owing to this the researcher was convinced to use this instrument. The questionnaire for teachers covered their educational level, professional and academic qualification, their teaching methods and strategies availability and accessibility of rust and un-rusted substances to pupils, class enrolment, time allocation and other matters.

\section{Data Collection Procedures}

Offinso College of Education Demonstration School been the located in the Offinso municipality was here the research was conducted and the data for the work was obtain from this premises. The researcher upon reaching the school observed everything of the school including its activities and structures. The researcher then wrote a proposal to the supervisor to seek permission to use the primary four class of the school for the data collection. This was done under the supervision of the head teacher and the class teacher as well. Copies of refined questionnaires were printed and distributed to the head teacher and the class teacher of class four. The researcher gave the participants some enough time to answer the question on the questionnaires.

The participants that is, the head teacher and classroom teacher responded and returned the questionnaire appropriately. Dealing with the pupils, questionnaires of fifty in number was sent to pupils and they answered neatly and returned them appropriately. But it was successful because they were guided furring the process and data collection was also done every day mostly during break hours. This was to avoid or limit any external influence. The library was not left out in the data collection process too. The researcher also considered the class size, library, availability and accessibility of rusted substances and non-rusted substances and time allocation was also not left out.

\section{Pre-Intervention Stage}

A pre-test was conducted to diagnose the pupils ability in science and they were made to answer questions in primary four (4) integrated science text book. In a clear context, the response of the questionnaires and observation made a confirmation of their challenges in science.

\section{Intervention Stage}

The main intervention for the study is the use of Activity Based Learning (Activity Method) to enhance learner understanding in the concept rusting. Activity Based Learning by Amutharadi \& Dr. Sirakumar (2014) means "a variety of activities designed based on constructivist principle for student's activity participatory rather than big passive listeners. As such, the researcher used variety of activities to activity 
engage pupils. The following are some of the processes and materials needed. Experiments to find out the use of activity based method to explain how some condition are necessary for rusting.

Charles \& Peter (2014) depicts the activity of pupils in the experiment as follows. Materials needed

- Labelled test tubes A, B, c

- Boiled water

- Anhydrous calcium chloride

- Cork

- Pieces of iron nails

- Cotton wool

\section{Procedure}

- Guide pupils to set up three test tubes as shown in figure 42.1 and guide them to label them A, B, C

- Into test tube assist pupils to place some quantity of anhydrous calcium chloride and seal it with a plug for some time to dry the air inside.

- Guide pupils to place some cotton wool on top of the calcium chloride and put two clean iron nails on top of the cotton wool in the dry test tube.

- $\quad$ Guide pupils to cover the test tube with the seal and leave it for a few days (3-4 days)

- Into test tube B, assist pupils to place some distilled water and boil it for a few minutes to drive off dissolved gasses

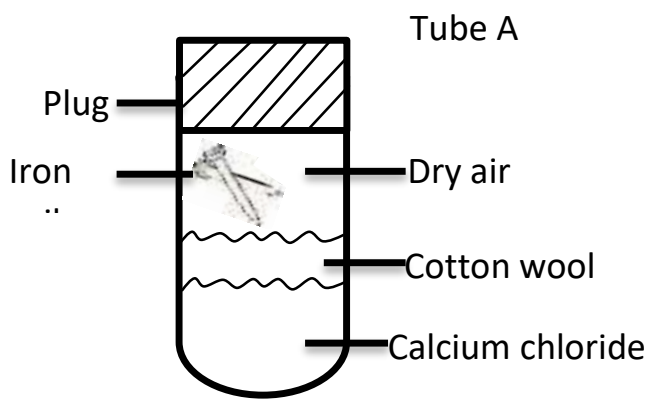

- Ask pupils to place two clean iron nails in the test tube quickly and seal of the surface by adding palm oil or any other oil or with a plug as seen in the figure B.

- Assist pupils to leave the test tube for few days (3-4) days.

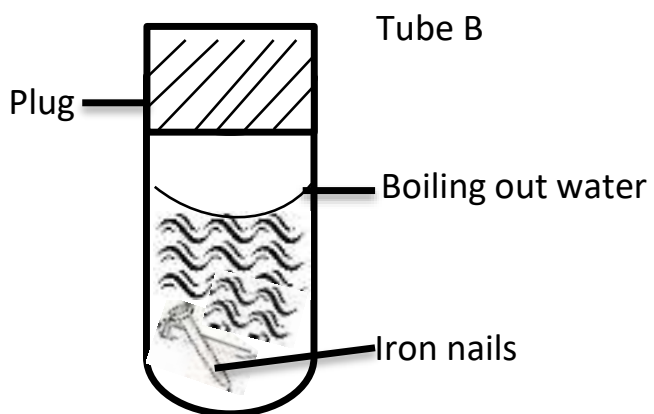

- Into the third test tube C, help pupils to place two iron nails into it and let them add some water and leave it open for a few days (3-4) days.

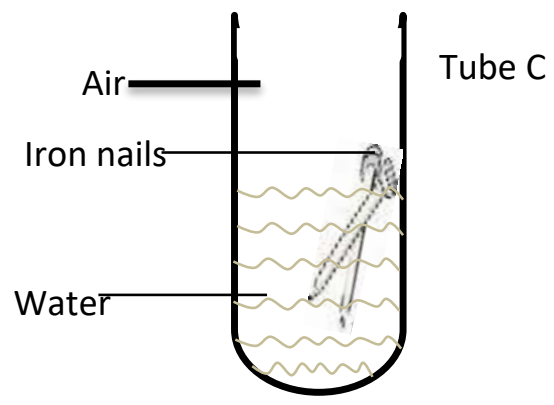




\section{Observation}

- After three or four (3-4) days it would be observed that, the iron nails in test tube c has been covered with a reddish brown layer. This is because of its exposure to air and water. The reddish brown layer in hydrated iron (II) oxide ( $\mathrm{Fe} 2 \mathrm{O} 3.3 \mathrm{H} 2 \mathrm{O})$ or rust.

- On the other hand, the nails in tubes a and B will have no reddish brown layer of rust because they had not been exposed on both and water.

- Nails in tube A was exposed to dry air only. While those in tube B were exposed to water only

- Assist pupils to arrange the three test tubes A, B. and C together as follows:

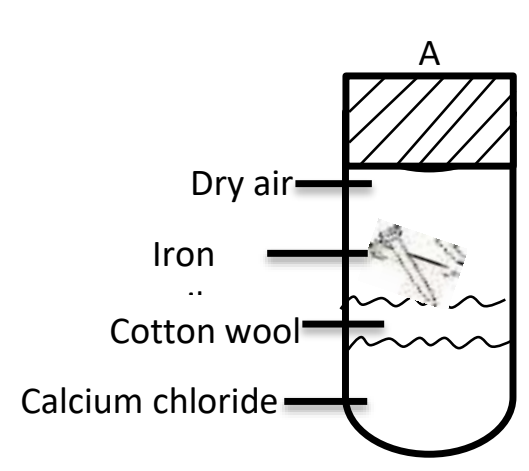

Air represent no water

Hence, no rust

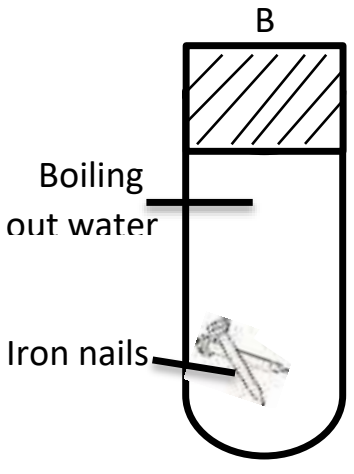

No air water, Hence, no rust

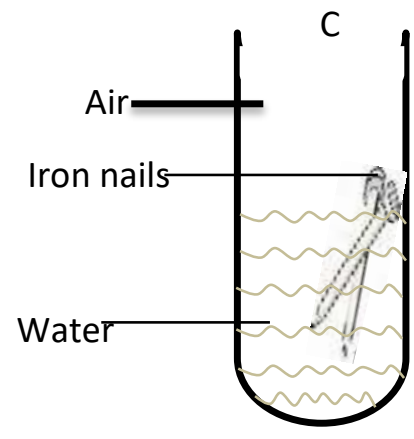

Air water

Hence, rust

\section{Conclusion}

- As pupils to deduced what the experiment produced as the two nails each in the test tube A, B and C are compared to the other two nails that was not used.

- Pupils therefore deduced that both water (moisture) and oxygen (air) are necessary conditions for the rusting of iron.

\section{Post Intervention Stage}

Post-test was conducted at the end of the intervention to check the effectiveness of the invention. The researcher gave sample questions for pupils to answer. The post-intervention test revealed a clear improvement in the pupil (s) understanding of magnetism.

\section{Data Analysis}

The responses to closed-ended item were coded and data were processed and analyzed by the use of computer software and other measures. Percentages and frequencies were used in presenting the data on respondents. The data from the three categories thus the head teacher, the class teacher and the pupils were analyzed manually to find general trends or themes. Lastly, the data analyzed were then organized in relation to the research questions and presented in the form of tables, charts and figures.

\section{Results and Findings}

The main focus of this study was to enhance the understanding of pupils' of Offinso College of Education primary four knowledge on the concept rusting. This chapter presents and discusses the results of the analysis of the data collected for the study. Test is considered a rich source of data in qualitative studies and may be solicited by Mail or in Pearson (1999) comments that when a researcher uses written narratives, it is extremely important to make it clear what the respondents have to write about. Polit and Hungler (1999) suggest that the researcher starts with some general questions or topics and allows the participants to tell stories in a narrative fashion.

The main ideas are causes of poor understanding of the concept rusting, the academic and professional competencies of teachers who teach Integrated Science in primary four of Offinso College of Education 
Demonstration School, the availability and accessibility of rusted and nonrated substances to the teacher and pupils, the regularity, punctuality and commitment of teachers to their work and techniques and strategies teachers use in teaching "rusting" in primary four of OFCE practice school. The biographical data of respondents are represented below.

Table 1: Shows the sex respondents

\begin{tabular}{|l|l|l|l|l|l|l|}
\hline \multicolumn{3}{|c|}{ Pupils } & \multicolumn{2}{l|}{ Teachers } & \multicolumn{2}{l|}{ Head teacher } \\
\hline Responses & No. & $\%$ & No. & $\%$ & No. & $\%$ \\
\hline Male & 26 & 52 & 2 & 67 & 1 & 100 \\
\hline Female & 24 & 48 & 1 & 33 & - & - \\
\hline Total & $\mathbf{5 0}$ & $\mathbf{1 0 0}$ & $\mathbf{3}$ & $\mathbf{1 0 0}$ & $\mathbf{1}$ & $\mathbf{1 0 0}$ \\
\hline
\end{tabular}

The result in table 1 shows that 26 representing 52\% out of 50 pupils that responded were males and 24 representing $48 \%$ were females. It was also observed that 2 representing $67 \%$ of the teachers that responded were males and 1 representing 33\% were females. For the head teacher, the respondent was a male and in totality thus all the fifty-four respondents, 29 which represents $54 \%$ were males and 25 which represents $46 \%$ were females.

\section{Research Question 1}

What are the perception of pupils about the concept rusting?

Table 2: Shows pupils' responses on the perception of pupils about the concept rusting.

\begin{tabular}{|l|l|l|}
\hline No. of items & $\begin{array}{l}\text { No. of } \\
\text { Respondents }\end{array}$ & $\begin{array}{l}\text { Percentage } \\
\%\end{array}$ \\
\hline $\begin{array}{l}\text { Teachers using varying methods and } \\
\text { technique in teaching. }\end{array}$ & 8 & 16 \\
\hline Teachers using concrete materials in teaching. & 7 & 14 \\
\hline $\begin{array}{l}\text { Teachers' number of times used in teaching } \\
\text { within the week. }\end{array}$ & 8 & 16 \\
\hline $\begin{array}{l}\text { Parents providing your basic educational } \\
\text { needs. }\end{array}$ & 15 & 30 \\
\hline $\begin{array}{l}\text { Do parents assist you in your homework/ } \\
\text { assignment? }\end{array}$ & 6 & 12 \\
\hline Pupils interest in the lesson. & 6 & $\mathbf{1 0 0}$ \\
\hline Total & $\mathbf{5 0}$ & \\
\hline
\end{tabular}

Source: Field Survey, 2019

The result in table 2 indicate that out of the 50 pupils that responded, 8 representing $16 \%$ of the respondents indicated that teachers use varying method, strategies and techniques in teaching integrated science. This implies that a few of the teachers do change the methods and strategies they use to teach integrated science. If out of 49 pupils only 8 of them attested that teachers use varying methods in teaching science and this practice is very disturbing because pupils have to bring their own knowledge to interact with the concept developing other skills but not just simply absorbing what is taught in the class. Skinner (1984) a very resourceful to education once said "Education is what services when what has been learned has been forgotten" When teachers vary their techniques in teaching science, then pupils can easily remember the concept taught. 
McDermott et al (2006) affirmed that, traditional instruction has failed to produce results in the desired understanding making is unsuitable for studies. To the researcher, most teachers must therefore strategize their strategies, techniques, methods so that the teaching of rusting would be effectively and efficiently made simple. This would put a stop to a lot of difficulties and challenges faced in learning by pupils.

The results in table 2 indicate that out of the 50 pupils that responded, 7 representing $14 \%$ of the respondents indicated that their teachers used Nacino Brown, Refal (1982) Curriculum and Instruction, An instruction to Methods of Teaching, The Macmillan press Ltd. concrete materials in teaching rusting. Azikiwe (1998) suggested that in the teaching profession, textbooks and other instructional materials such as newspaper, magazines, journals and other publications help both teachers and pupils to have better and quicker understanding of what pupils learn but only 7 out of 50 pupils responded that teachers use concrete materials which is very bad and might be a major cause of poor understanding of rust concept of pupils. If teaching aid are whatever is taught in the classroom. Chukwu (2007:2008) suggested in support of the notion that, the absence of these materials in most schools constituted problems for effective learning process. Nacino (1982) again explained that during the teaching and learning process, it is important to appeal to all the senses of the child. This can be only done through the use of teaching and learning materials. For this reason, it become important for the teacher to use teaching aids during lesson delivering.

The result also shows that out of 50 pupils who responded, 8 which forms $16 \%$ of the respondents indicated teachers' number of times used in teaching science within the week. This means that a lot of teachers rarely teach science and this contributed to the poor understanding of the concept rusting. The researcher therefore observed that the amount of time pupils spend on Integrated Science is quite small according to Anderson et $\mathrm{al}$; (1985). Hope (2018) report that since time in instruction is a critical factor in teaching and learning, it should be contended that a successful integrated science lesson should include large amount of time for teaching the concept of rusting. On the contrary, teachers fail to have frequencies science lesson with pupils and owing to that pupils are not able to have proper understanding of rusting.

The results from the table also portrayed that is representing $30 \%$ of the pupils who responded indicated that their parents provided them with basic that, "the parent as a cell acts only with love and respect and it dominates the understanding, affection, sacrifice and childcare". Since education is a continuous process, it starts right from the child's immediate environment and this environment in context is home. Research has shown that a child who grows up in a home where learning is supported and a viewed as very important performs well in class. As such, effective learning is encouraged in a siren environment Claudia et al (2008). The researcher has deduced that if parents provide needed books, the required money (finances), motivation, the needed skills and knowledge expected of pupils before formal education, the necessary sound mind pupils need will be created (unknown). Because education is the process of creating a sound mind in a sound body.

Again, the table shows out that 50 pupils that responded, 6 representing $12 \%$ of the respondents indicated that parents do help their wards in their assignments (home works). This points out that pupils mostly depend on what they are taught in class, whether they understand or not without any support in the house. Comparing what is aid in the various literature above, one can declare that the above points are the major contributory factors of pupils poor understanding of the concept rusting.

Table 3: Shows parents responses on the cause of pupils poor perception about the concept rusting.

\begin{tabular}{|l|l|l|}
\hline No. of items & $\begin{array}{l}\text { No. of } \\
\text { Respondents }\end{array}$ & $\begin{array}{l}\text { Percentage } \\
\%\end{array}$ \\
\hline $\begin{array}{l}\text { Ability of provding ward with educational } \\
\text { needs. }\end{array}$ & 8 & 16 \\
\hline Motivation and reinforcement of wards. & 5 & 10 \\
\hline Assisting wards at home with academic work. & 8 & 16 \\
\hline Numbers of days pupils attend school in a & 21 & 42 \\
\hline
\end{tabular}




\begin{tabular}{|l|l|l|}
\hline week. & & \\
\hline $\begin{array}{l}\text { How often do you help your ward in practical } \\
\text { work? }\end{array}$ & 8 & 16 \\
\hline Total & $\mathbf{5 0}$ & $\mathbf{1 0 0}$ \\
\hline
\end{tabular}

Source: Field Survey, 2019

The results in table 3 above shows parents responses on the cause of poor understanding of the concept rusting. The table clearly depicted that 8 out of 50 parents who responded to the problem, implying $16 \%$ of the parents provided for the wards in terms of the basic educational needs. On the contrary, $84 \%$ do not provide their wards with such needs to their wards. This is very much disturbing because if the pupils do not get any support in their education from the house, their learning abilities would be negatively affected. Some of the basic educational needs includes textbooks, notebooks, exercise books, pens and pencils, uniforms, Baker et al., (2002) commented that, the more parents are involved with their children, the more positive learning and general life outcome occur. Bronfenbrenner, (1986) says, family is the primary influence of grandchildren and sets the stage for how they grow and develop. But since parents do not help their wards by providing their educational needs, pupils waste the leisure time on unnecessary activities to the detriment of their learning. Azikiwe (1998) was not left out but commented that, teaching aids and materials for learning are essential ingredients for teaching and learning especially in science related topics. The researcher upon analyzing these facts hence suggest that, parents must provide their wards with their basic educational needs so that it will fuel the activities of both teaching and learning and even encourage them to understand topics in science especially the concept of rusting.

The results in the table again shows that $10 \%$ of the respondents also responded to the item that whether or not they are motivated by their parents. This percentage represents 5 respondents. Wade \& Moore, (1998) cited that students who excel academically often have parents who are interested in their children's learning from an early age and who engage in supportive learning activities. Since motivation are reinforcement is both internal (intrinsic) and external (extrinsic) factors that stimulate desire and energy in people to be continually interested to a job, role or subject. As the most widely adopted human right document in history, ratified by 192 nations, UNCROC provides a powerful backdrop to the care of children Act, Boshier (2007, pg.7). Keith (1999) cited that teaching and learning aids generally are essential ingredients for teaching and learning especially in the concept rusting and are helpful resources of motivation. The researcher therefore believes strongly that lack of motivation on the part of parents can contribute to pupils' difficulty to learn science in general and precisely rusting as a concept.

The table further displays that out of 50 parents that responded, 8 representing $16 \%$ of the respondents indicated that they offer assistance to their wards at home with their academic activities. Academic assistance at home involves helping pupils' in their home works / assignment, helping pupils to read over their notes, helping pupils to practice what was taught at school in the house and even helping them to gather some information for their projects. The research has made it known that bulk of their parents leave early to work and report late, aside that some who close early are mostly illiterates in the sense that they cannot read and write this is very bad environment for pupils who are very weak in academics.

The results in the table also shows that 21 parents thus $42 \%$ of the respondents answered the number of times their wards attended school in a week which means that their wards always present in school. This information clearly shows that more than $50 \%$ of parents did not respond to that and it is obvious that their wards attend classes twice, thrice or even once a week which is very bad and might be a major contributory factor to pupils poor understanding of the concept rusting. This is why the researcher is of the view that if parents make sure that their wards attend school very frequently in order to have effective understanding of what is taught at school. Parents who are literates would always make sure that their wards are in school unlike the illiterates.

The results finally shows that 8 parents out of 50 respondents representing $16 \%$ responded on how often they helped wards in their practical works. The practical aspects of Integrated Science often begins from the home especially relating to rusting, where some substances such as nails, roofing sheets, iron buckets etc are 
found rusted in the house. The immediate environment of the child is where learning actually begins. If parents involve themselves in assisting their wards in the practical works of science especially rusting which is commonly around, will help enhance the understanding of the rusting concept.

Table 4: Depicts teachers' responses on causes of poor understanding of the concept of rusting.

\begin{tabular}{|l|l|l|}
\hline No. of items & $\begin{array}{l}\text { No. of } \\
\text { Respondents }\end{array}$ & $\begin{array}{l}\text { Percentage } \\
\%\end{array}$ \\
\hline Do you have high educational background? & 1 & 33.3 \\
\hline $\begin{array}{l}\text { Use of varying techniques and methods in } \\
\text { teaching. }\end{array}$ & 0 & 0 \\
\hline Use of appropriate TLMs in teaching. & 0 & 0 \\
\hline Motivation and reinforcement of pupils. & 0 & 0 \\
\hline Finding out and solving problems of pupils. & 1 & 33.3 \\
\hline Taking care of special children & 1 & 33.3 \\
\hline Total & $\mathbf{3}$ & $\mathbf{1 0 0}$ \\
\hline
\end{tabular}

Source: Field Survey, 2019

The results in table 4 shows that out of 3 teachers that responded, 1 representing $33.3 \%$ of the respondents indicated that he had attained high educational competency. The educational competency comprise the amount of time available of teaching and how it is used by teachers and students have direct bearing on students' achievement Lockhead \& Komeman (1989). This means that the period of time allocated to the study of Integrated Science and the effective utilization of that period for the teaching and learning determines pupils understanding in science topics. The researcher in this note observed that, the educational competency comprises regularity and punctuality of teachers. If out of 3 teachers only 1 responded to punctuality, then it implies that teachers were absence once or twice every week. But the ability of teachers to teach rusting effectively to enhance learning depends mainly on their competence and punctuality.

The table also shows that out of 3 teachers that responded, none representing $0 \%$ of the respondents responded to the use of varying techniques and methods in teaching. This means that teachers do not vary their techniques and methods they use in teaching Integrated Science. This might be a major cause of pupils misunderstanding of the concept of rusting. Carey, (1985) cited, the idea that understanding is domain specific to thinking about conceptual understanding. In many cases, students have developed partially correct ideas that can be used as the foundation for further learning and this was cited by Clement et al, (1989). The researcher also base on this to comment that, although understanding is constructed internally by an individual, the process may be influenced by external factors including techniques and methods of teaching. Hence, it becomes necessitated to combine technique, methods and strategies so as to make the teaching and learning of rusting simple. If teachers do not vary their techniques in teaching, pupils would continue to have difficulties.

The researcher also observed that none of the teachers responded to the item that asked teachers to indicate whether or not they help them. This was very absurd on the part of the teachers, the duty of the teachers is not only teaching pupils from context and content but also to help pupils to overcome their problem. Aristotle sees education as the process of creating a sound mind in a sound body. As any process needs planning, implementation and decision making, teaching rusting also needs planning, implementing and taking decision on its outcome. The researcher confidently says that irregular teaching of Integrated Science may cause the pupils so dearly. Hence, materials must be employed in the teaching and learning process which mostly turn out to be a motivating source to pupils Azikiwe (1998).

Out of 3 teachers responded, none responded to the motivation and reinforcement of pupils. The ability to understand and control emotions influences the literacy development process by determining the child's 
ability to create meaningful relationships with other people and cooperate with others. Johnson (2010) suggested that emotional factors are related to child's emotional wellbeing as well as the ability to understand, express and control emotions. Pupils with emotional problems often exhibit learning deficit because their ability to integrate with other members of society. It is from this suggestion that the researcher generalized that pupils with emotional problems cannot comprehend to acquire the understanding of the concept taught.

The table also shows that out of the 3 teachers that responded, 0 representing $0 \%$ of the teachers indicated that they use the appropriate teaching and learning materials in teaching of rusting. Considering the statistics, it is very abysmal to record such a null record in using teaching and learning materials in teaching the concept rusting. McDermott, (1996) cited, instructional materials has been associated with sharply increased performance among pre-service elementary teaching, studying several science topics. Atwood et al, (2006) also cited that materials are structured to encourage students to take responsibility for their own active learning. To the researcher, teaching and learning materials must be available at all times to promote metacognitive processing because students must compare the explanation they have held in the conceptual framework with explanations that explain the data they generate through investigation.

\section{Research Question 2}

What are some of the opposing factors against the shows teachers concept?

Table 5: Shows teachers responses on how available and accessible are teaching and learning materials to teachers of OFCE Practice School.

\begin{tabular}{|l|l|l|}
\hline No. of items & $\begin{array}{l}\text { No. of } \\
\text { Respondents }\end{array}$ & $\begin{array}{l}\text { Percentage } \\
\%\end{array}$ \\
\hline $\begin{array}{l}\text { How pupils are reinforced during science } \\
\text { lesson. }\end{array}$ & 1 & 33.3 \\
\hline How often assignments are given. & 1 & 33.3 \\
\hline Availability and accessibility of TLMs. & 1 & 33.3 \\
\hline Total & $\mathbf{3}$ & $\mathbf{1 0 0}$ \\
\hline
\end{tabular}

Source: Field Survey, 2019

The results in table 5 show clearly that out of the 3 teachers that responded, 1 of the teachers representing $33 \%$ of the total respondent show the availability of materials help in the reinforcement of their pupils. This means $64 \%$ of teachers could not respond to the item 3 on the questionnaire for teachers. As instructional materials are instruments that help in quicker and better understanding of whatever is taught. Johson, (2010) cited that, emotional factors are associated with the child's emotional wellbeing as well as ability to understand, express and control emotions. If there is availability of materials, pupils' interest in the materials alone could make them forget their problems and as such, there is the need of TLM's. Furthermore, when teachers have TLM's at their disposal, instruction would be made very simple.

The table also portrays that out of the 3 teachers that responded, only 1 representing $33.3 \%$ of the respondents indicated that the materials were available and accessible. When materials are accessible, learning of rusting would be made very simple. Effective teaching and learning of any subject would not only stimulate pupils interest in the subject but also enhance their achievement in examination. The materials includes different teaching aids or apparatus which a classroom teacher employs to facilitate his or her teaching for the achievement of stated objective.

Teachers who hereby do not access to materials may sometimes even teach out of content and will not be able to achieve the objectives at the end of the day. This form of teaching is mostly abstractly.

The results in the table finally display that 1 representing $33.3 \%$ of the total respondents of 3 indicated how often exercises were given to pupils. Carefully planning of teaching and learning materials reinforce pupils' understanding and teachers should therefore plan, select and organize materials fort teaching rusting. When 
materials are available, teachers give exercises from them. This mean that the rest of the respondents do not have access to materials and these causes poor understanding of the concept rusting.

Table 6: Shows pupils response on the availability and accessibility of materials in teaching rusting as a concept of Offinso College of Education Practice School.

\begin{tabular}{|l|l|l|}
\hline No. of items & $\begin{array}{l}\text { No. of } \\
\text { Respondents }\end{array}$ & $\begin{array}{l}\text { Percentage } \\
\%\end{array}$ \\
\hline $\begin{array}{l}\text { Enjoying teachers' lesson during delivery of } \\
\text { rusting lesson. }\end{array}$ & 14 & 28 \\
\hline Using concrete materials in teaching rusting. & 16 & 32 \\
\hline Provision of educational needs by parents. & 20 & 40 \\
\hline Total & $\mathbf{5 0}$ & $\mathbf{1 0 0}$ \\
\hline
\end{tabular}

Source: Field Survey, 2019

Pupils' response on how available and accessible materials are in Offinso College of Education Practice School. To address this issue, items 2, 3 and 6 on the questionnaire for pupil's asked them to indicate the availability and accessibility of materials in teaching the concept rusting in Offinso College of Education Practice School.

The results in the table also shows that out of the 50 pupils that responded, 14 representing $28 \%$ of the respondents indicated their enjoyment in rusting lesson. The indication here is that if only 14 out of 50 pupils enjoy the rusting, then majority of the pupils do not enjoy the rusting lessons since there are no or inadequate materials in learning. If pupils are exposed to materials frequently during lessons, this will arouse their desire and pleasure to love to study such subject each day in and out. This is a clever point that says pupils must be taught with concrete materials and when this happens, pupils will gain better and quicker understanding of whatever is been taught (Hope, 2018).

The results in table 6 show clearly that out of the 50 pupils that responded, 16 representing $32 \%$ of the respondents responded that teachers used concrete materials in teaching them during rusting lesson. Demirel (1999) cited, while preparing lesson / daily plans, teachers should also think about the concrete materials they will use in their lessons in order to decide where and how to use these materials in a proper way, and to make their arrangements accordingly. Paykock, (1991); Simsek, (2003) suggested that, all materials and resources used for developing the desired skills, knowledge, attitudes and values in students are regarded within the scope of concrete materials.

The results finally shows that 20 out of 50 pupils representing $40 \%$ indicated that parents provide their educational needs. The rest of the respondents objected to this question indicating that they were never in any way receive any support educationally by parents. Others who even responded positively was provided inadequately. Light \& Keller (1994) contributed to factors that influence academic performance, stated that pupils usually perform better when they have books and study aids to foster learning. Materials that aid in learning as to the researcher includes textbooks, exercise books, uniforms, journals and other publications must be provided by parents to pupils so that they will have sound mind to study which will enhance better and easier understanding of whatever the teacher teaches.

\section{Research Question 3}

How can the concept rusting be taught effectively and efficiently through Activity Based Learning?

Table 7: Shows pupils' response on how can the concept rusting as taught professionally through the use of Activity method.

\begin{tabular}{|l|l|l|}
\hline No. of items & $\begin{array}{l}\text { No. of } \\
\text { Respondents }\end{array}$ & $\begin{array}{l}\text { Percentage } \\
\%\end{array}$ \\
\hline
\end{tabular}




\begin{tabular}{|l|l|l|}
\hline $\begin{array}{l}\text { Do teachers vary their approach in teaching } \\
\text { you integrated science (rusting)? }\end{array}$ & 21 & 42 \\
\hline $\begin{array}{l}\text { How often are you (pupils) engaged in } \\
\text { integrated science lessons. }\end{array}$ & 17 & 34 \\
\hline Do you enjoy clearing the rusting lesson? & 12 & 24 \\
\hline Total & $\mathbf{5 0}$ & $\mathbf{1 0 0}$ \\
\hline
\end{tabular}

Source: Field Survey, 2019

The table 7 results is an indication that out of the 50 respondents, 21 respondents representing $42 \%$ are attesting that teachers vary the approach they use in teaching rusting. This indicated that not all teachers use the right approach in their lesson. Teachers have to use different methods in teaching which is basically Activity Based Learning and must on this note vary their methods, strategies and skills they use in teaching rusting so that pupils can be actively be engaged in the learning process whiles teachers become facilitators and guides guiding their activities.

The results in table 7 shows that out of 50 pupils that responded 17 representing $34 \%$ of the respondents indicated that they are often engaged (pupils) in Integrated Science lessons. Pupils are individuals that easily get their attention swayed to different activities mostly when those activities interest them. Teachers are therefore encouraged to actively engage pupils in their daily lessons mostly assigning them to tasks with will need them to render and run errands before, during and after the lesson. As such pupils will never forget the taught lessons for a very good number of years and even explain to the understanding of others.

The table finally shows that out of the 50 pupils that responded, 12 representing $24 \%$ of the respondents indicated pupils enjoyment in class during the concept rusting's lessons. Teachers must make sure pupils feel comfortable in the classroom, there must be good teacher-pupils relationship existing between them so that pupils can tell the teacher whenever there is a problem so that the work of the teacher will be made simple and since there is good interpersonal relationship, pupils will therefore enjoy rusting lesson and this will aid understanding of rusting concept.

Table 8: Shows teachers response on how the concept rusting was taught professional through the use of Activity Method of Learning.

\begin{tabular}{|l|l|l|}
\hline No. of items & $\begin{array}{l}\text { No. of } \\
\text { Respondents }\end{array}$ & $\begin{array}{l}\text { Percentage } \\
\%\end{array}$ \\
\hline What is your educational qualification? & 1 & $33.3 \%$ \\
\hline Do you motivate and reinforce your pupils. & 1 & $33.3 \%$ \\
\hline Taking care of pupils with special needs. & 1 & $33.3 \%$ \\
\hline Total & 3 & 100 \\
\hline
\end{tabular}

Source: Field Survey, 2019

The results in table 8 shows that out of the three (3) teachers that responded, only one (1) of them representing $33.3 \%$ of the respondents indicated that they had only one individual attaining higher educational level. This is very worrying to pupils academic performance. Alexander (2000) cited that, "the tendency to evaluate teacher qualities on the basis of students performance is further emphasized." Studies have found somewhat stronger and more consistently positive influence of education and pedagogical coursework on teacher effectiveness (Ashton \& Crocker, 1987: Eversion et al 1985, Ferguson \& Womach 1993, Cuyton \& Farokhi, 1987). Since majority of the respondents have not attained higher educational level, they lack or have inadequate required skills, methods and the appropriate ways to manipulate teaching and learning materials to enhance the understanding of the magnetism concept. Alexander (2000) further contended that by good teaching, we mean that the content taught accords with disciplinary standard of 
adequate and completeness and the methods employed are age appropriate morally defensible and undertaken with the intention of enhancing learners competencies with respect to content.

It is also shown clearly that 1 representing $33.3 \%$ of the three (3) respondents responded to the item that asked them to state whether or not they had special needs pupils in their class and how best they took care of them. It was observed that teachers only have little control of pupils with special needs. They have inadequate skills and knowledge to cater for such children in their class. Pupils who suffer from psychological characteristics such as visual impairment inability to speak well and inability or partial hearing ability. Verhosen et al (2011) cited that, psychological challenges affect pupils negatively and so pupils with such special problems must be well taken care of. This will help an individual to develop competencies in certain areas of difficulties and enhance development of manipulation skills.

Table 9: Shows raw scores of pupils' pre-test.

\begin{tabular}{|c|c|}
\hline Names of pupils & Pre-test (out of 5) \\
\hline Adasi Mensah Morrison & 3 \\
\hline Adadzawa Selom David & 2 \\
\hline Acheampong Melchizedek & 0 \\
\hline Antwi Emmanuel & 1 \\
\hline Asare Eugene & 0 \\
\hline Akwasi Appiah & 1 \\
\hline Boakye Thomas & 0 \\
\hline Boakye Russel & 0 \\
\hline Daasebere Kwame & 1 \\
\hline Duah Collins & 2 \\
\hline Dankwah Richard & 0 \\
\hline Dekyi Malachi & 0 \\
\hline Dwamena Kwabena Samuel & 1 \\
\hline Appiah christian & 0 \\
\hline Fatawu Ibrahim & 0 \\
\hline Fosu Prince & 2 \\
\hline Lukman Abdul Rasheed & 2 \\
\hline Oppong Tawiah Kelvin & 0 \\
\hline Sanusah Jamal & 1 \\
\hline Takyi Richmond & 1 \\
\hline Umar Anafi & 0 \\
\hline Wiafe Stephen & 1 \\
\hline Wiafe Torres & 1 \\
\hline Akomeah Bonsu Maxwell & 3 \\
\hline
\end{tabular}




\begin{tabular}{|c|c|}
\hline Owusu Adade Alexander & 0 \\
\hline Sarfo Emmanuel & 0 \\
\hline Aminatu Mohammed & 0 \\
\hline Agyapong Bio Kereen & 1 \\
\hline Appiah Queendybell & 0 \\
\hline Annor Akua Marylin & 1 \\
\hline Awuni Mamunatu & 0 \\
\hline Boamah Veronica & 0 \\
\hline Batung Harriet & 1 \\
\hline Issaka Sakinatu & 2 \\
\hline Mansah Naomi & 1 \\
\hline Ntoo Felicia & 0 \\
\hline Nti Doris & 1 \\
\hline Nyantakyiwa Juliet & 0 \\
\hline Osei Adoma Hannah & 0 \\
\hline Osei Linda & 0 \\
\hline Osei Victoria & 3 \\
\hline Opoku Boateng Jasmine & 1 \\
\hline Sekyere Perpetual & 1 \\
\hline Wiafe Fernandy & 0 \\
\hline Yeboah Agyemang Lindywell & 1 \\
\hline Adwubi Nancy & 1 \\
\hline Gyakye Sallom & 2 \\
\hline Agoriwo Charity & 0 \\
\hline Mohammed Khadijah & 1 \\
\hline Zanu Daniel & 1 \\
\hline
\end{tabular}

Based on the raw scores of pupils' performances, a frequency distribution table was constructed. Below are pupils results on the frequency distribution table.

\begin{tabular}{|c|c|c|c|}
\hline Score & Tally & Frequency & Percentage \% \\
\hline 0 & HIH HWH HWH HH // & 22 & $44 \%$ \\
\hline 1 & HH HH HIH I/I/ & 19 & 38 \\
\hline 2 & HII I & 6 & 12 \\
\hline 3 & /// & 3 & 06 \\
\hline
\end{tabular}




\begin{tabular}{|l|l|l|l|}
\hline 4 & - & 0 & 0 \\
\hline 5 & - & 0 & 0 \\
\hline Total & & $\mathbf{4 9}$ & $\mathbf{1 0 0}$ \\
\hline
\end{tabular}

From the table above, 22 representing $44 \%$ of the respondents out of 50 pupils that were used for the study scored 0 out of 5 marks. 19 pupils out of 50 pupils scored 1 out of 5 marks representing 38\%. 6 pupils out of 50 pupils scored 2 out of 5 marks representing $12 \%$ and 3 pupils managed to score 3 out of 5 marks been the pass mark. On the contrary, none of the pupils used for the test scored 4 marks and 5 marks respectively. Is very unfortunate that, as many as $94 \%$ scored below the past mark 2.5 .

The scores of pupils are also presented on the bar graph below.

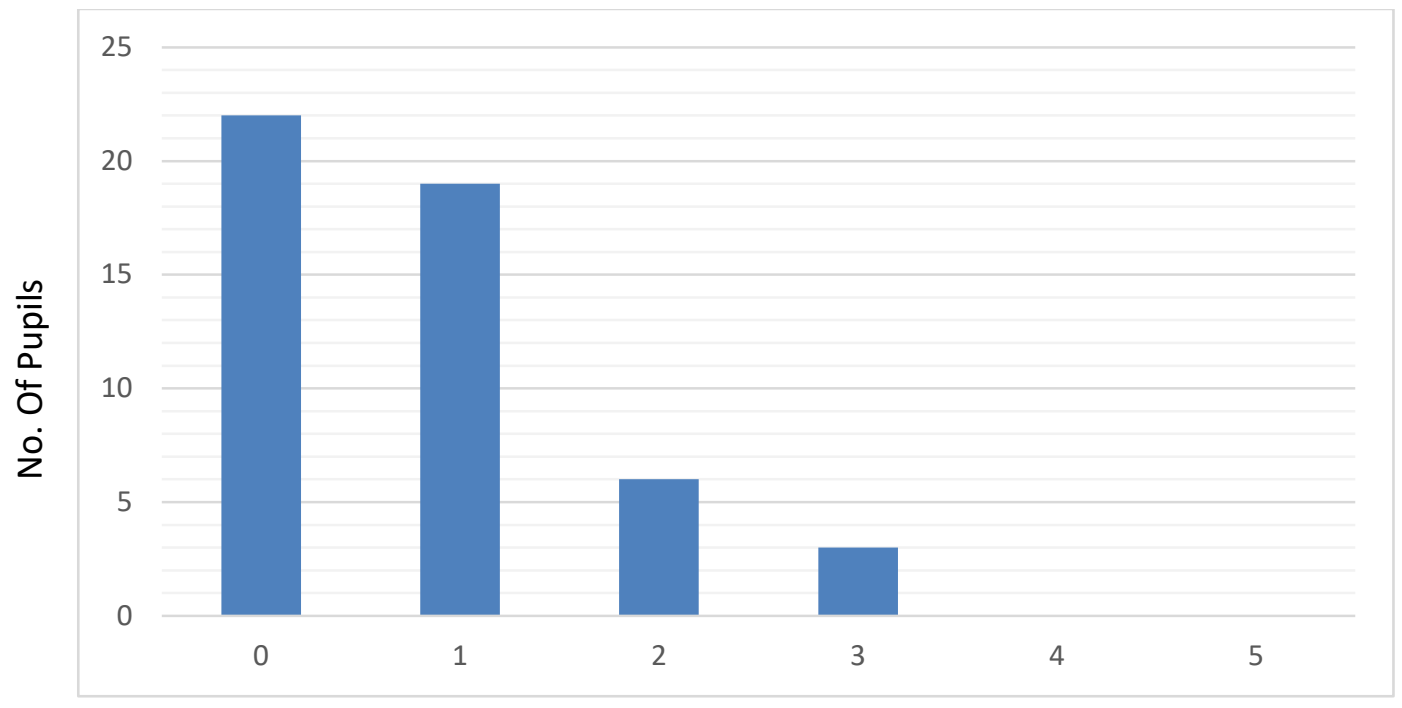

Marks of Pupils

From the graph, the frequencies were presented vertically, that is the y-axis and the marks scored were presented horizontally on the $\mathrm{x}$-axis.

Table 10: Shows raw scores of pupils post-test.

\begin{tabular}{|l|c|}
\hline Names of pupils & Post-test (out of 5) \\
\hline Adasi Mensah Morrison & 4 \\
\hline Adadzawa Selom David & 5 \\
\hline Acheampong Melchizedek & 3 \\
\hline Antwi Emmanuel & 5 \\
\hline Asare Eugene & 3 \\
\hline Akwasi Appiah & 5 \\
\hline Boakye Thomas & 3 \\
\hline Boakye Russel & 4 \\
\hline Daasebere Kwame & 4 \\
\hline Duah Collins & 4 \\
\hline Dankwah Richard & 5 \\
\hline Dekyi Malachi & 3 \\
\hline Dwamena Kwabena Samuel & 4 \\
\hline Appiah Christian & 5 \\
\hline Fatawu Ibrahim & 3 \\
\hline Fosu Prince & 3 \\
\hline Lukman Abdul Rasheed & 3 \\
\hline Oppong Tawiah Kelvin & 4 \\
\hline
\end{tabular}




\begin{tabular}{|l|l|}
\hline Sanusah Jamal & 3 \\
\hline Takyi Richmond & 3 \\
\hline Umar Anafi & 4 \\
\hline Wiafe Stephen & 5 \\
\hline Wiafe Torres & 3 \\
\hline Akomeah Bonsu Maxwell & 4 \\
\hline Owusu Adade Alexander & 5 \\
\hline Sarfo Emmanuel & 3 \\
\hline Aminatu Mohammed & 5 \\
\hline Agoriwo Charity & 5 \\
\hline Adwubi Nancy & 5 \\
\hline Agyapong Bio Kereen & 4 \\
\hline Appiah Queendybell & 4 \\
\hline Annor Akua Marylin & 4 \\
\hline Awuni Mamunatu & 4 \\
\hline Boamah Veronica & 5 \\
\hline Batung Harriet & 5 \\
\hline Issaka Sakinatu & 3 \\
\hline Gyakye Shallom & 4 \\
\hline Mansah Naomi & 5 \\
\hline Ntoo Felicia & 5 \\
\hline Nti Doris & 5 \\
\hline Nyantakyi Juliet & 4 \\
\hline Osei Adoma Hannah & 3 \\
\hline Osei Linda & 3 \\
\hline Osei Victoria & 5 \\
\hline Opoku Boateng Jasmine & 5 \\
\hline Sekyere Perpetual & 3 \\
\hline Wiafe Fernandy & 4 \\
\hline Yeboah Agyemang Lindywell & 4 \\
\hline Mohammed Khadijah & 5 \\
\hline Zanu Daniel & 3 \\
\hline & \\
\hline & \\
\hline & \\
\hline
\end{tabular}

Below are pupils' results on the frequency distribution table depicting the outcome of the post-test.

\begin{tabular}{|l|l|l|l|}
\hline Score & Tally & Frequency & Percentage \% \\
\hline 0 & - & 0 & 0 \\
\hline 1 & - & 0 & 0 \\
\hline 2 & - & 0 & 0 \\
\hline 3 & HIH HIH HI / & 16 & 32 \\
\hline 4 & HIH HIH I I & 16 & 32 \\
\hline 5 & HIH HIH III & 18 & 36 \\
\hline Total & & $\mathbf{5 0}$ & $\mathbf{1 0 0}$ \\
\hline
\end{tabular}

From the table above, none of the respondents out of 50 pupils that were used for the study scored 0,1 and 2 marks. Whilst on the contrary, out of 50 pupils, 16 pupils scored 3 marks representing $32 \%$ of the respondents that responded to the post-test. Out of 50 pupils again, 16 pupils representing $32 \%$ of the respondents scored 4 marks. Finally, 18 pupils out of 50 pupils used in the test scored 5 marks of 5 marks. This clearly indicate a vast improvement of pupils performance. This is very encouraging and also outstanding.

The performance of pupils' post-test is recorded on the bar graph below. 


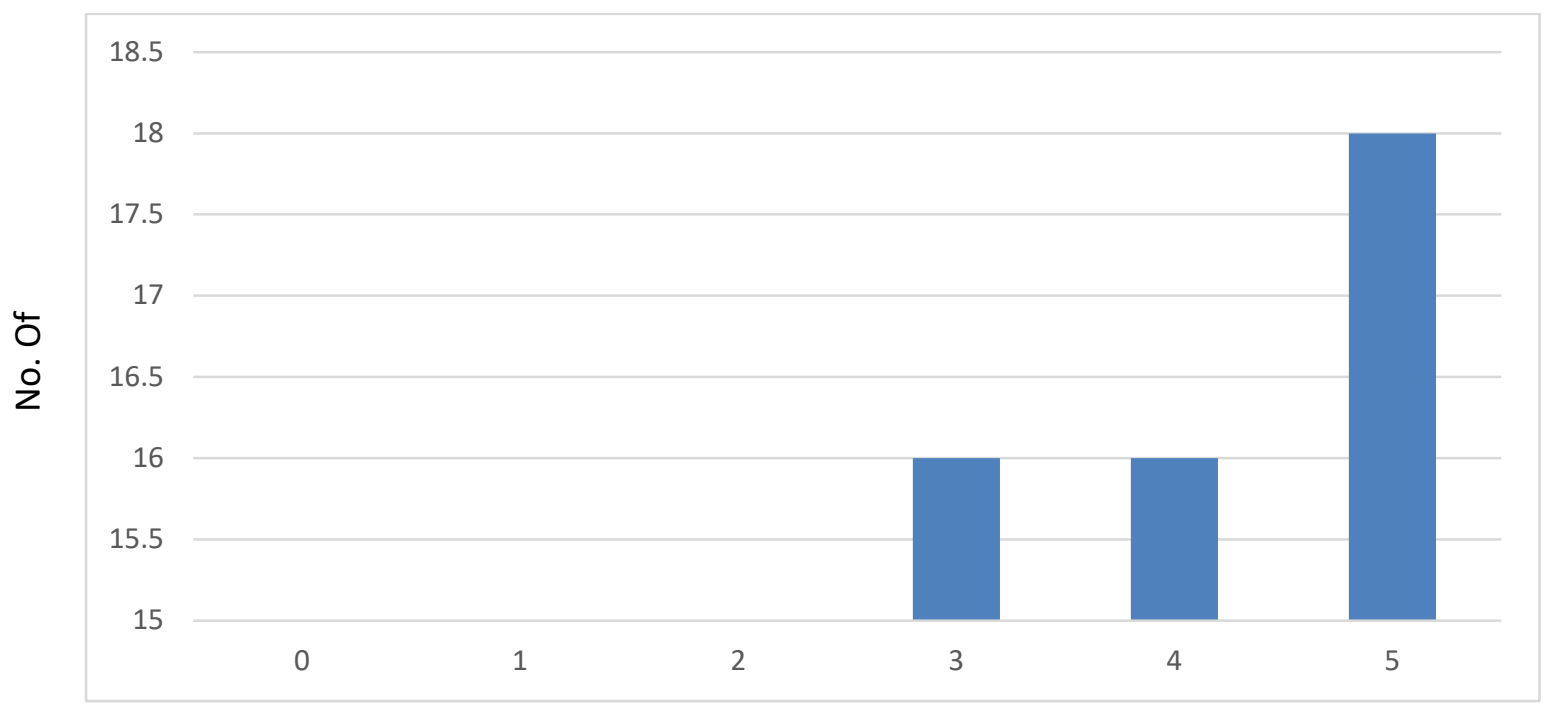

Marks scored by pupils

Below is a simplified graph that compares both the pre-test to the post-test's results from the two exercises.

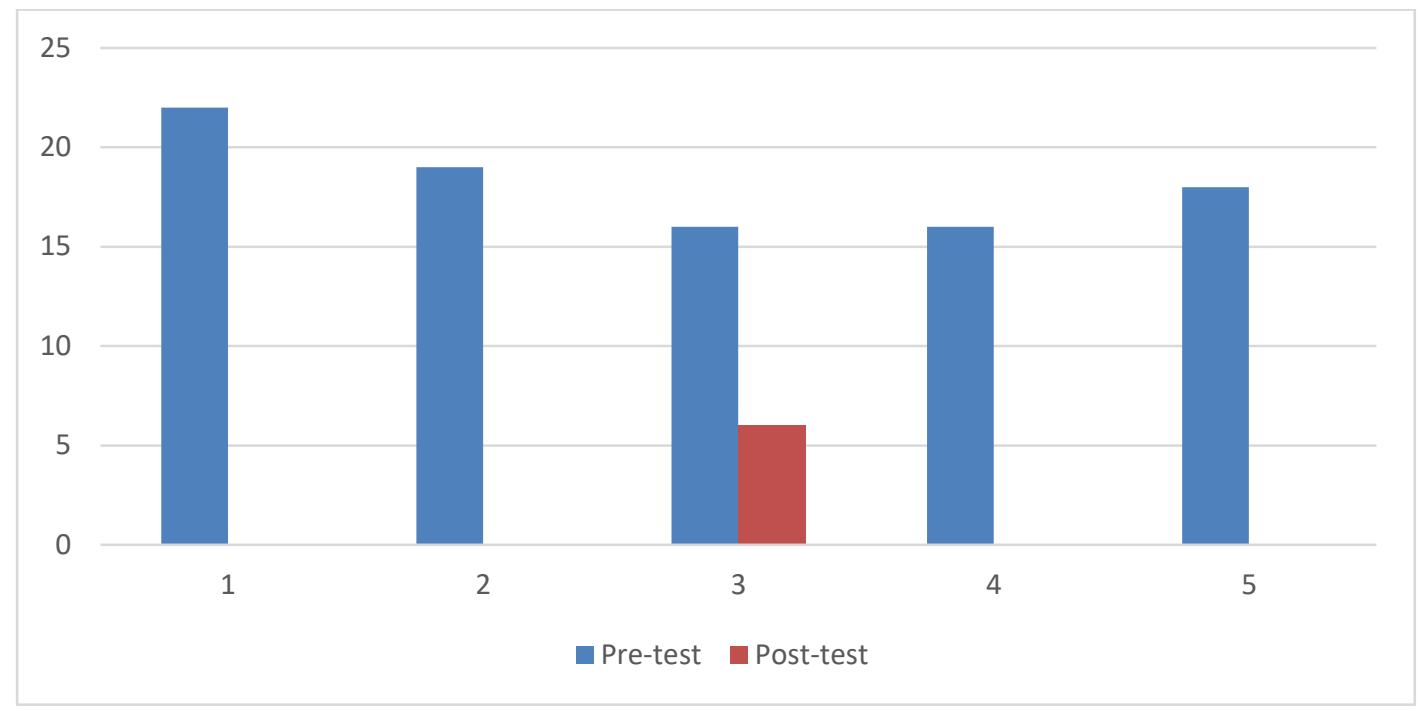

\section{Overview of the Study}

In recent times, some concerns have been expressed about the low performance of pupils four (4) in OFCE Practice School due to poor understanding of rusting. This concern is very sad in relevance to the teaching and learning process. These concerns prompted the researcher to embark on the study to make out what's actually happening in the school with regards to rusting. The objective of this study was therefore to identify school-related causes of poor understanding of rusting among OFCE Practice School pupils four (4). Specifically, the study sought to find out: What are the perception of pupils about the concept rust, what are some of the opposing factors against the concept and how can the concept rusting be taught effectively and efficiently through activity method?

The study employed the action design and the simple random sampling technique. The population of the research consisted of 3 primary four (4) Integrated Science teachers, their head teacher and 50 primary four (4) pupils out of 150 pupils in primary four (4). The pupils were selected through a simple random sampling method. The instruments used to identify school-related method of enhancing pupils understanding of rusting among primary four (4) pupils were interview guide observation guide and questionnaire.

\section{Summary of Major Findings}

The study aimed at finding out school-related methods of enhancing understanding of rusting concept among primary four (4) pupils of Offinso College of Education Demonstration School. The following 
involve the summary of the finding from the data collected and analyzed. The summary was done around the research questions which were centered on school related causes of poor understanding of rusting concept.

Research Question One asked: What are the perception of pupils about the concept rust? The finds was a cause of varying techniques, methods and strategies in teaching by teachers. Teachers do not vary their techniques and methods in teaching and this was a major cause of pupils having a conception about rusting. McDermott (2006) cited that the traditional instruction has failed to result in the desired understanding so it is unsuitable for study. Hero \& Stetzer (2006) also seconded that science topics becomes difficult to teach using only one technique and that teachers therefore have to combine several techniques to enhance quicker and better understanding. Another cause is the academic and professional competencies which regularity and punctuality was included and this was confirmed by Lockhead and Komeman that the amount of time available for teaching and how it was used by teachers and learners have direct bearing on students achievements and progress.

Again, another cause was the use of appropriate teaching and learning materials in teaching rusting and it was known that most of the teachers do not teach using teaching aids in the teaching of rusting which is creating poor perception of pupils about the concept rusting. It is pointed that, commenting that teaching and learning materials which are helpful to the teachers and pupils which maximize learning in various areas. Another cause was the ability of teachers to understand and control emotions that were influencing the learning of rusting thus motivation of pupils. Based on the finding, it is clear that pupils with emotional problems often exhibit learning deficit because of their inability to integrate with other members of society and the child's ability to create meaningful relationship with other people and cooperate with others. This was therefore supported by Johnson (2010) that emotional factors are related to a child's emotional wellbeing as well as the child's ability to understand, express and control emotion.

The availability and accessibility of materials to teach and learn rusting was another cause to move pupils to have good conception and perception about rusting concept. It was known that materials in teaching rusting concept were not available and accessible to teachers and pupils. Azikiwe (1998) stated that teaching and learning materials are generally essential ingredients for teaching especially in science topics of which rusting is not excluded and they are powerful sources of motivation. This was therefore clear that the unavailability and inaccessibility of teaching and learning materials was a cause for pupils poor perception of rusting.

In addition, the findings further showed another cause to the questions was the frequency at which teachers teach rusting. It was shown clearly that teaching and learning of rusting was very rare and it is therefore an undeniable fact that pupils are not able to learn and understand due to teachers' inability to have frequent rusting lessons with them. Since teaching of rusting was irregular, pupils therefore found it difficult to learn and it was a very major cause of poor perception of rusting.

Research Question Two: What are some of the opposing factors against the concept? The findings from this research is that amongst the competencies, none of the teachers had attained high educational background which Alexander (2000) commented that "the tendency to evaluate teacher qualities on the basis of students performance is further emphasized". Studies therefore found somewhat stronger and more consistently positive influence on education and pedagogical coursework on teacher effectiveness (Ashton \& Coker 1987: Everston et al, 1985: Ferguson \& Womack, 1993: Guyton \& Farokhi, 1987).

It was also observed that, regularity and punctuality was also compromise and the findings showed clearly that teachers were not frequent and regular in the teaching of rusting. It was also known that behaviour is more strongly established through frequent connections of stimulus and response. The teachers' inability to teach pupils frequently led to serious misunderstanding of rusting. Fielding \& Pearson (1994) suggested that time in instruction was a critical factor in learning program and irregularity on the part of teachers was a very major contribution of pupils' difficulty to understand rusting and is a factor fighting against the concept.

To add up, majority of teachers did not vary their techniques and strategies in teaching rusting and was always using a single technique. It was also shown that there was lack of reinforcement and motivation of pupils. Pupils with psychological problems often exhibit learning deficit because of their inability to 
integrate with other members of the society. This clearly shows that lack of reinforcement would lead to learning and teaching problems. The ability of teachers to cater for special needs of pupils is another factor against the concept rusting and this was clearly shown from the findings that, there were pupils with special needs but teachers were unable to cater for them. It was shown that special need children lack or have inadequate skills and knowledge to understand text and teachers also had no idea on how to cater for them. This was a major contributory factor amongst the competencies of teachers.

Research Question Three: How can the concept rusting be taught effectively and efficiently through Activity Based Method? McDermott (2006) cited again that the traditional instruction has failed to result in the desired understanding so it is unsuitable for study. Activity Based Method has been effective and efficient where pupils are activity engaged into the activities of learning and they are allowed to touch and feel materials, use materials in experiments, observe and make conclusions and recommendations about a particular work. Teachers only stand in as facilitators and give guidelines on how to attain perfect results. Teachers must on this note use Activity Based Method to engage pupils where they learn and can explain concepts better than any other method of learning and teaching.

\section{Other Findings}

Other findings were that majority of the pupils were misplaced when it came to Integrated Science and specifically rusting. From the researcher's own experience, a child may be in particular stage but his age and mind might not be developed though to learn and understand primary four lessons. An example is basically, the average age for primary four (4) pupils is ten (10) years plus (4). Despite that, some pupils of eight and nine years even at time seven years do find themselves in there. This means that the child was misplaced when it comes to reality and if a child is misplaced, and he or she is to learn what is above what his mind can absorb. He or she becomes frustrated and turns to dislike the rusting concept.

\section{Conclusions}

The purpose of the study was found out through questionnaires and interviews the school-related activities to enhance pupils understanding of rusting among primary four pupils of Offinso College of Education Practice School. In view of the findings of the study, the following conclusions were drawn. Teachers who teach Integrated Science (rusting) did not have the basic requisite knowledge in the teaching of rusting and they were not professionally trained teachers of higher education. Because of teachers lacking or having inadequate professionals and trainees of higher education standard, they were not applying those methods, skills and techniques that they are to use for the betterment of pupils easily understanding. The unavailability and inaccessibility of teaching and learning materials, time allocation of Integrated Science, teachers irregularity and misplacement of pupils in a class above their mental level impeded on pupils' progress and success in rusting concept. The researcher is of the view that if all hands are put to the desk, the impeding conditions or situations can be curbed to improve on the enhancement of pupils interest in learning rusting.

\section{Recommendations}

From the review of relevant literatures and the results of the study, the following recommendations are made for reflection and practice.

1. The importance of Integrated Science plays a role in the field of education and even in the learning process; it is therefore recommended that Integrated Science must be taught at least four times a week for an hour each day.

2. The importance of teaching and learning materials must be considered, and more especially a science laboratory where experiments can be conducted by pupils through the Activity Based Method of teaching and learning. Pupils must be given the chance to touch and feel some materials both metals and non-metals, materials that can rust and others that cannot rust. The government and other stakeholders in education must come to the aid of primary schools by providing these materials.

3. It is also recommended that the pupils must be motivated and reinforced to improve and enhance their easy understanding of rusting. Special needs pupils too should not be left out of the scene but must be given the necessary attention and needs that merit them. 
4. Finally, it is further recommended that pupils be given placement test. This test will discourage the practice of misplacement of some pupils where a child will be struggling to understand simple text which should understood by primary four (4) pupils and this will avoid the dislike of Integrated Science (rusting).

\section{Suggestion for Further Research}

It is suggested that those wishing to do further investigation on this study may continue since research has a unique cyclical process but these researchers must consider the curricula, teachers handbooks used by teacher training programs and investigate the commitment of teachers.

Acknowledgements: Augustine Adjei (Dean of Students' Affairs-OFCE), Justice Adom-Adjei, Bridget Adom-Adjei, Herbert Adom-Adjei, Augustine Adom-Adjei, Rose Adjei (Mrs.), Diana Adutwumwaa and Lawrencia Adjei.

\section{References}

[1] [www.oed.com/view/Entry/169112 "rust, n.1 and adj"] check/ur1=value (help). OED online oxford university press, June 2018.Retrieved 7 July 2018

[2] Adjei, A. et. al; (2018) using Bar Magnets and Substances to enhance the understanding of Magnetism Among Basic Five Pupils at Offinso College of Education Practice School. Journal of Applied Research. DOI: 10.31142/rajar/v4i12.02. Volume: 04Issue: 12 December-2018

[3] J. Shamhuna, M.S. Abdalla and a. M. Abdulla, "Education for All Assessment 2001-2003" no. July 2014

[4] American Association for the Advancement (2003). Benchmarks for Science Literacy. New York: Oxford University Press.

[5] Ary, D., Jacobs, L.C., \& Razaview, A. (2002). Introduction to research in education (6 ${ }^{\text {th }}$ ed). Text: USA.

[6] Atwood, R., Christopher, J., \& McNall, R. (2006). Middle school teachers understanding of standards - based light concept before and after instruction. San Francisco, CA:

[7] Azikiwe, U. (1998) Study Approaches of University Students; WCCI Region II Forum Vol.2, Lagos

[8] Baidoo, E. H. (2018). Using Bar Magnets and Magnetic substances to enhance the understanding of magnetism among Basic five (5) pupils at Offinso College of education practice school. (Unpublished)

[9] Brody, Michael (2006). Montana State University faculty. Retrieved from the web. http://arexpeditions.mpntana.edu/index.php.Jan 2008

[10] Carey, S. (1985). Conceptual change in childhood. Cambridge, MA: MIT Press.

[11] Charles and Peter Aseidu, Aki Ola Integrated Science for Secondary Schools (2014)

[12] Dampson, D.G. \& Mensah D. K.D. (2012). A practical Guide to Action Research and case study research. Amakom - Kumasi: fatless publication Limited

[13] Ferguson, P.\& Wemat, S. T. (1993) The Impact of Subject Matter and or Teachinh Performance. Journal of Teacher Education, 44 (1), 155-163.

[14] Harper, Douglas "Science” online Etymology Dictionary. Retrieved September 20, 2014

[15] Interview, David Des Marais" NASA.2003. Archived from the original on 2007 - 11- 13

[16] Johnson, M. \& Susan, M. (2012). Theories and Techniques of Behaviour Change; Health Psychology Review, 6:1, 1-6.

[17] Lockhead, M.E. \& Komeman, A. (1988). School effects on students achievement in Nigeria and Switzerland. Washington D.C.

[18] McCarthy, D. J. (1973) New Perspective on Teacher Education. London: Jossey-Bas Publishers

[19] McDermott, L. (1991). Milikan Lecture 1990: What we teach is what is learned: Closing the gap American Journal of physics.

[20] McDermott, L., Aaron, P. Shaffer \& Stetzer, M. (2006). Improving the preparation of K-12 teacher through physics education research. American Journal of physics. 74, 763-767.

[21] Mills, G. E. (2011) Action Research; AGuide for the Teacher Researcher ( ${ }^{\text {th }}$ Ed.) Boston: Pearson

[22] Nacino Brown, Rental (1982). Curriculum and Instruction, An instruction to Methods of Teaching, The Macmillan press Ltd.

[23] P. Obanya, J. Habani and P. Okebukola, "guide to teaching and learning in higher education" 1996.Emil 
[24] P. Obanya, J. Shabani and P. Okebukola, "Guide to teaching and Learning in higher education 1996.

[25] Roy Carlsten Manager, Technical/support services, Rusf Corp. Uhlig, H.H. (1985). Corrosion and corrosion control, $3^{\text {rd }}$ ed. New York: John Wiley and Sons

[26] Schonbwein, C. (1936). Pogg. Ann; 37, 390

[27] Sivakumar, (2014). Impact of Activity Based Learning on Learning Science at Primary Level. (Unpublished)

[28] Sund, Robet B.; Bishop, Jeanne (1980). Accent on science. C.E. Merrill. ISBN9780675075695. ARCHIEVED FROM ORIGIANL ON 2917/11/30.

[29] Test (n.d.). In Google Web. Retrieved from, www.google.com/test. Accessed on $24^{\text {th }}$ February 2015

[30] The chief Examiner's Report (2012). In www.ghanawaec.org/examiner. Retrieved from www.ghanawaec.org/exams/examiner-BECE.aspx Accessed on 15th December 2014

[31] The world book Encyclopedia, (1996). Ed. volume 16 world book, inc. Fetze London Sydney. Toronto: Scott Fetza Company.

[32] Turgoose, S., (1982). The Nature of Surviving Iron Objects, Conversation of Iron (ed.R.W. Clarke and S. M. Blackshaw), National Maritime Meseum, London.1-17

[33] Uhlig, H. H. Corrosion and Corrosion Control, Ed.II, John Liliey \& Sons, Inc. USA (1971).

[34] Wildey, H., \& Wallace, J. (1995) Understanding Teaching or Teaching for Understanding: Alternative Framework for Science classroom; Journal of Research in Science Teaching. 